\title{
Effect of drought length on the performance of cabbage (Brassica oleracea var capitata) in the forest-savannah transition zone, Ghana
}

\author{
E. Ackah ${ }^{1}$ (1) R. Kotei ${ }^{2}$
}

Received: 6 February 2020/ Accepted: 22 September 2020/Published online: 7 November 2020

(C) The Author(s) 2020

\begin{abstract}
The drought tolerance of Cabbage, Brassica oleracea var capitata (Oxylus) was investigated by subjecting the initial, development and mid growth stages to varying drought lengths of 5, 7, 9, 11, 13 and 15 days in a $7 \times 3$ factorial experiment to determine the effect of each drought period at each growth stage on growth and yield. Data on number of opened leaves/plant, leaf area index (LAI), leaf chlorophyll content, head size and yield/ha were recorded due to drought effect at each growth stage. Analysis of variance at $5 \%$ probability level indicated that drought periods of 5-15 days at the initial stage significantly reduced number of leaves, LAI and head size. Significant reduction in chlorophyll content and yield were due to drought beyond 11 and 5 days respectively at the initial stage. Number of opened leaves increased significantly with increasing drought length at the development stage; critical at 11 days drought. Significant reductions in LAI at the development and mid stages were critical at 11 and 9 days respectively whilst chlorophyll content was significantly reduced at both the development and mid stages by all drought periods. Significant reduction in head size at the development and mid stages was critical at 7 days. Generally, the drought tolerance of cabbage increased from the initial to the mid-stage. To maintain economic yields of cabbage in the forest-savannah
\end{abstract}

E. Ackah

bigemma1995@gmail.com

1 Department of Crop and Soil Science, College of Agriculture Education, University of Education, Winneba, Mampong-Ashanti, Ghana

2 Department of Agriculture Engineering and Mechanization, College of Agriculture Education, University of Education, Winneba, Mampong-Ashanti, Ghana transition zone, the initial and development stages could tolerate drought stress up to 5 days whilst the mid stage could tolerate up to 7 days.

Keywords Oxylus · Drought · Brassica oleracea $\cdot$ Growth stages $\cdot$ Chlorophyll $\cdot$ Forest-savannah $\cdot$ Yield

\section{Introduction}

Cabbage (Brassica oleracea L. var. capitata) is a vegetable crop grown worldwide including African countries (Grzywacz et al. 2010). It is widely adapted to the tropical climates (Blankson et al. 2013). In Ghana, cabbage production is mostly popular among peri-urban and urban dwellers in response to high demand (Timbilla and Nyarko 2004). Cabbage is also grown in cities and rural communities in Ghana and it serves as an important source of livelihood for many smallholder farmers in Ghana (Baiphethi and Jacobs 2009).

The world's annual production of cabbage is around $70,644,191$ tons with an average yield of about $29.23 \mathrm{ton} /$ ha (Kidane 2016). The major production constraints mostly reported in Ghana are insect pests, diseases, the need for high fertilizer input and the high cost of pesticides (Williamson et al. 2008).

The changing patterns of climatic parameters like temperature and precipitation are emerging major threats for vegetable production in the forest-savannah transition zone (Challinor et al. 2014). The effect of water stress is expected to increase with increasing length of drought. An anticipated report revealed that up to $30 \%$ of the yields from rain-fed farming in some south Asian countries could be lost to increasing drought stress by 2050 (Intergovernmental Panel on Climate Change [IPCC], 2007). Though 
cabbage production in the forest-savannah transition environment of Ghana is lucrative during the dry season (November to February), inadequate water availability limits production (Ezeaku et al. 2014).

Rise in temperature as well as increasing drought frequency and length at any stage of crop growth can affect the normal growth, flowering, pollination, fruit development and subsequently decrease crop yield (Hedhly et al. 2009). Changes in chlorophyll content are often measured as a symptom of water stress (Majumdar et al. 1991).

Cabbage has been classified as moderately susceptible to water stress, with the head formation period being more sensitive (Shannon and Grieve 1998). Maggio et al. (2005) reported that drought stress decreased the total head yield of cabbage from 50.5 to 17.5 tons/ha without stating the length or duration. In Brassica napus cultivars, water stress reduced chlorophyll $a+b$ content by $38 \%$ compared with the adequately watered plants (Paclik et al. 1996).

The Forest-Savannah Transition Zone is known to experience drought spells even in the main rainy seasons varying from 1 to 3 weeks. For this reason, farmers who depend mostly on rain are usually faced with the challenge of selecting a suitable planting date for their seasonal crops. Cabbage production in the Forest-Savannah Transition Zone thus experiences increasing frequency and length of drought which is bound to occur at any of the growth stages of the crop. Although several studies confirm the significant effect that drought stress can depict on cabbage production, none of these studies indicated how long, within a particular growth stage, will the effect of drought manifest. This study therefore sought to unveil the critical length of drought occurrence (in days) at the growth stages of cabbage from which growth and yield will be significantly affected.

\section{Materials and methods}

\section{The study area}

This study was conducted at the College of Agriculture Education, University of Education, Winneba, the Mampong campus during the dry season between December, 2017 and April, 2018. Mampong-Ashanti lies North of Kumasi within the Forest-Savannah Transition Zone between the Guinea Savanna in the North and Forest region of the South of Ghana, and lies between longitudes $00^{\circ} 00^{\prime} 05^{\prime \prime} \mathrm{W}$ to $10^{\circ} 00^{\prime} 30^{\prime \prime} \mathrm{W}$ and latitudes $60^{\circ} 00^{\prime} 55^{\prime \prime} \mathrm{N}$ to $70^{\circ} 00^{\prime} 30^{\prime \prime} \mathrm{N}$ of the equator. The Mampong Municipality lies within the Wet Semi-Equatorial Forest Zone. Due to human activities like charcoal production, lumbering and bush fires, the forest vegetation, particularly the NorthEastern part, has been reduced to Savannah. The area has an average annual rainfall of $1270 \mathrm{~mm}$ and two rainy seasons. The major rainy season starts in March and ends in August whilst the minor is between September and November. The remaining months spans the harmattan (dry) season. The average annual temperature is $27{ }^{\circ} \mathrm{C}$ with variations in mean monthly temperature ranging between 22 and $30{ }^{\circ} \mathrm{C}$ (Kotei et al. 2015).

\section{Experimental design and drought application}

The experiment was a $7 \times 3$ factorial in a Randomized Complete Block Design (RCBD). The factors included drought length with seven (7) treatments and three (3) growth stages, each replicated thrice (3). The growth stages, including "initial/vegetative growth stage, development/head formation stage and mid/head filling stage" were subjected to 5, 7, 9,11,13 and 15 days of complete drought. A control treatment (0 days drought) which received water continuously throughout the experimental period was set aside for the experiment. Seeds for the research (Oxylus variety) were obtained from a certified Agro-Chemical shop and seedlings raised under conducive nursery conditions for three (3) weeks and before transplanting. To avoid transplanting shock, all transplants were watered for 4 days before drought application. The application of drought however ended in March, 2018 while experimental plants continued through the "late growth stage" in April, 2018.

Water supply to plants was completely based on how the drought periods were imposed and a well scheduled drip irrigation system. Water requirements were estimated using monthly Reference Evapotranspiration (ETo) obtained from Mampong Meteorological Agency (MMA) and Crop coefficient (Kc) of growth stages of the crop, according to FAO (2018) were used in computing various parameters for calibrating the drip system.

The experimental field comprised of three main blocks representing the three growth stages with each measuring $11 \mathrm{~m} \times 12.6 \mathrm{~m}$ with $1 \mathrm{~m}$ path from each. Each main block (growth stage) was further divided into six sub blocks, representing 6 drought periods $(5,7,9,11,13$ and 15 days droughts) each measuring $2 \mathrm{~m} \times 12.6 \mathrm{~m}$ with a $1 \mathrm{~m}$ path from each other. Each sub block was further divided into three plots, measuring $2 \mathrm{~m} \times 4.2 \mathrm{~m}$ with a $1 \mathrm{~m}$ path between plots. The control treatment ( 0 days drought) comprised of a single block $(2 \mathrm{~m} \times 12.6)$ divided into three plots $(2 \mathrm{~m} \times 4.2 \mathrm{~m}$ each). Each treatment plot hosted 24 plants resulting in a total of 1368 experimental plants, including the control. 


\section{Calibration of the drip system}

Twenty (20) containers were used to collect water randomly from emitters scattered between the first and last dripping points in $15 \mathrm{~min}$ and the average volume of water was determined to be $150 \mathrm{~mL}=0.15 \mathrm{~L}$. Dripping rate of the system was estimated using Eq. 1.

Drip per minute $=\frac{0.15 \mathrm{~L}}{15 \mathrm{~min}}=0.01 \mathrm{~L}^{-\min }$

\section{Crop evapotranspiration (ETc)/water requirement}

The crop evapotranspiration (ETc) for the growth stages representing the water requirement of each particular stage were estimated using Eq. 2.

$\operatorname{ETc}\left(\mathrm{mm}^{- \text {day }}\right)=$ Mean monthly ETo $\times \mathrm{Kc}$

Mean monthly ETos for the four (4) months period of the study and Kcs for the growth stages of cabbage are presented in Tables 1 and 2 respectively.

\section{Irrigation time}

In order to match the estimated ETc with the dripping rate $\left(\mathrm{L}^{-\mathrm{min}}\right)$, ETc for each growth stage was converted from $\mathrm{L}^{- \text {day }}$ to $\mathrm{mm}^{- \text {day }}$.

By conversion, $4.1 \mathrm{~mm}^{- \text {day }}=0.3 \mathrm{~L}^{- \text {day }}$ (Arku et al. 2012).

Hence,

Converted $\operatorname{ETc}\left(\mathrm{L}^{- \text {day }}\right)=\frac{\operatorname{ETc}(\mathrm{mm} / \text { day }) \times 0.3 \mathrm{~L} / \text { day }}{4.1 \mathrm{~mm} / \text { day }}$

Time to run the system in minutes per day was estimated using Eq. 4.

Irrigation time $=\frac{\text { Converted ETc }(\mathrm{L} / \text { day })}{\text { Dripping rate }(\mathrm{L} / \mathrm{min})}$

Estimated time for running the irrigation system during the growth periods are presented in Table 3.

\section{Evaluation of the drip system}

The drip irrigation system used in the study was evaluated of its delivery efficiency by estimating its uniformity

Table 1 Monthly ETo for study area. Source: Meteorological Service Department, Mampong agency

\begin{tabular}{lcccc}
\hline Month & Jan & Feb & Mar & Apr \\
\hline ETo $\left(\mathrm{mm}^{- \text {day }}\right)$ & 4.94 & 5.39 & 4.63 & 3.86 \\
\hline
\end{tabular}

Table $2 \mathrm{Kcs}$ for the growth stages of Brassica Oleracea. Source: FAO (2018)

\begin{tabular}{lllll}
\hline Crop stage & Initial & Development & Mid & Late \\
\hline Kc & 0.4 & 0.7 & 0.95 & 0.9 \\
\hline
\end{tabular}

coefficient $(U C)$ and emission uniformity (EU) using discharge measurement data from 20 emitters. The uniformity coefficient equation according to Dudek and Fernandez (2015) and the emission uniformity equation were employed to compute the uniformity parameters of the drip system. These equations are simple and are widely used in the present days (Al-Ghobari, 2012; Asif et al. 2015):

Uniformity coefficient $(U C)=100\left(1-\frac{S D}{\bar{q}}\right)$

$S D=\sqrt{\frac{1}{n} \sum\left|q_{i}-\bar{q}\right|^{2}}$

Emission uniformity $(E U)=\left(\frac{q_{a l q}}{\bar{q}}\right) \times 100$

\section{Coefficient of variation $\left(C V_{M}\right)$}

According to Asif et al. (2015), the coefficient of variation is generally used as a measure of emitter flow variation due to variation in manufacturing characteristics of the emission devices. The $\mathrm{CV}$ describes the quality of the material and processes used to manufacture the emission devices. It is determined from flow measurements for several identical emission devices and is computed using Eq. 8.

$C V_{M}=\frac{S D}{\bar{q}}$

where $q_{i}=$ discharge of emitter $\mathrm{i}, \bar{q}=$ overall average of emitter discharges, $\mathrm{n}=$ number of emitters, $q_{\text {alq }}=$ average low/min-quarter emitter discharge, $S D=$ standard deviation, $C V_{M}=$ manufacturers' coefficient of variation for emitters.

\section{Emission uniformity rating}

Dudek and Fernandez (2015) rated emission uniformity values as follows:

$$
\begin{array}{ll}
<77 \%=\text { Very poor } & 77-82=\text { Poor } \\
83-90 \%=\text { Acceptable } & >90 \%=\text { Excellent }
\end{array}
$$

The emission coefficient $(E U), 97.07 \%$ estimated from the catch results collected in this study indicates that the drip system used for water application was highly efficient with only $2.93 \%$ water loss. The uniformity coefficient $(U C)$ and $\mathrm{CV}_{\mathrm{M}}$ values were $95.68 \%$ and 0.043 respectively. 
Table 3 Estimated times for running the irrigation system

\begin{tabular}{|c|c|c|c|c|c|c|c|}
\hline Stage (days) & $\begin{array}{l}\text { Month/period } \\
\text { (days) }\end{array}$ & $\begin{array}{l}\text { ETo } \\
\text { (mm/day) }\end{array}$ & $\mathrm{Kc}$ & $\begin{array}{l}\text { ETc } \\
(\mathrm{mm} / \text { day })\end{array}$ & $\begin{array}{l}\text { Converted ETc } \\
\text { (L/day) }\end{array}$ & $\begin{array}{l}\text { Dripping rate (L/ } \\
\text { min) }\end{array}$ & $\begin{array}{l}\text { Time } \\
\text { (min/day) }\end{array}$ \\
\hline Initial (20 days) & Jan-20 & 4.94 & 0.40 & 1.98 & 0.14 & 0.01 & 14 \\
\hline \multirow{2}{*}{$\begin{array}{l}\text { Development } \\
\text { (30 days) }\end{array}$} & Jan-4 & 4.94 & 0.70 & 3.46 & 0.25 & 0.01 & 25 \\
\hline & Feb-26 & 5.37 & 0.70 & 3.76 & 0.28 & 0.01 & 28 \\
\hline \multirow[t]{2}{*}{ Mid (20 days) } & Feb -2 & 5.37 & 0.95 & 5.10 & 0.37 & 0.01 & 37 \\
\hline & Mar-18 & 4.63 & 0.95 & 4.40 & 0.32 & 0.01 & 32 \\
\hline \multirow[t]{2}{*}{ Late (20 days) } & Mar-12 & 4.63 & 0.90 & 4.17 & 0.30 & 0.01 & 30 \\
\hline & $\mathrm{Apr}-8$ & 3.86 & 0.90 & 3.47 & 0.25 & 0.01 & 25 \\
\hline
\end{tabular}

According to Asif et al. (2015), the ranges of Cv values and their appropriate interpretations are as follows:

$$
\begin{array}{ll}
>0.4=\text { Unacceptable } & 0.4-0.3=\text { Low } \\
0.3-0.2=\text { Acceptable } & 0.2-0.1=\text { Very good } \\
<0.1=\text { Excellent } &
\end{array}
$$

Thus, the UC and CV values estimated from the catch data show high efficiency of the drip system.

\section{Growth and physiological measurements}

Number of opened leaves, leaf area index (LAI) and chlorophyll content index were measured on 9 plants from each replicate at the end of each growth stage. Normal irrigation resumed after each drought treatment. For the initial stage, the leaves of selected plants were counted and the average estimated to represent the number of leaves of a single plant before head formation. For the development and mid stages, the outer leaves were counted and the average estimated at the end of the stages.

The leaf area of selected crops was measured indirectly using Imagej software version 1.46r (Scurlock et al. 2001). The selected leaves were captured at equal height above ground level. The images were then cropped in adobe Photoshop CS6 to obtain the actual area of the canopy, excluding parts of the ground which appeared in the original image. The resultant image was transported into the imagej where the area of the canopy was estimated. The area of land occupied by the selected plants was also estimated. Leaf area index was then calculated as $\frac{\text { canopy area }}{\text { ground area }}$ (Scurlock et al. 2001).

Leaf chlorophyll content index was measured using the Chlorophyll meter (CCM-200 Plus). The leaf chlorophyll content index estimates were taken 3 times from six fully expanded leaves, two (2) leaves each from the bottom set, middle set and upper set of leaves of selected plants. The average chlorophyll content was estimated in CCI.

\section{Yield and yield components}

Cabbage heads were harvested at the end of the "late growth stage" when heads were fully filled and thus, felt hard when squeezed. Head size/girth and weight were measured with fiber glass tape and electronic scale respectively. Head weights were used to estimate yield (tons/ha).

\section{Statistical analysis}

Data on growth parameters including number of opened leaves, LAI and leaf chlorophyll content index were subjected to a one-way analysis of variance analysis (ANOVA) with drought length as the varying factor for each growth stage whilst data on head size and yield were subjected to two-way analysis of variance with drought length and growth stage as varying factors using Genstat statistical package windows version 11.1 (2008). This analytical strategy was employed owing to physiological differences of the crop at the different growth stages which could result in biased growth at the stages. As a result, comparing growth at the stages may be unfair; however, the resultant effect of drought at the different growth stages on yield parameters are fairly comparable. Where significant differences existed, mean separation was done using the LSD criterion at 5\% (0.05) probability level.

\section{Results}

\section{Number of opened leaves/plant}

With increasing drought length, number of opened leaves decreased at the initial stage, increased at the development stage but remained constant during the mid-stage. Analysis of variance of results (Table 4), indicated significant $(P$ $\leq 0.05$ ) reduction in number of leaves at the initial stage 
Table 4 Mean number of opened leaves as influenced by drought length at different growth stages of B. oleracea var capitata

\begin{tabular}{|c|c|c|c|c|c|c|c|c|c|}
\hline \multirow[t]{2}{*}{ Growth stage } & \multicolumn{7}{|c|}{ Drought length (days) } & \multirow[t]{2}{*}{ LSD } & \multirow[t]{2}{*}{$\mathrm{CV}(\%)$} \\
\hline & 0 & 5 & 7 & 9 & 11 & 13 & 15 & & \\
\hline Initial & $13^{\mathrm{a}}$ & $11^{\mathrm{b}}$ & $10^{\mathrm{b}}$ & $10^{\mathrm{b}}$ & $10^{\mathrm{b}}$ & $10^{\mathrm{b}}$ & $10^{\mathrm{b}}$ & 1.4 & 7.6 \\
\hline Development & $19^{\mathrm{a}}$ & $19^{\mathrm{a}}$ & $19^{\mathrm{a}}$ & $19^{\mathrm{a}}$ & $22^{\mathrm{b}}$ & $21^{\mathrm{ab}}$ & $21^{\mathrm{ab}}$ & 2.0 & 5.7 \\
\hline Mid & 20 & 20 & 20 & 20 & 20 & 20 & 20 & $1.2 \mathrm{~ns}$ & 3.3 \\
\hline
\end{tabular}

Between column means bearing different superscripts differ significantly $(P \leq 0.05)$ due to all drought periods (5-15 days) compared to the control. The control plants produced the highest number of leaves (13), preceded by 5 days drought stressed plants (11 leaves) whilst the rest of the drought periods, although similar in their effects on number of leaves at the initial stage, each resulted in $23.1 \%$ reduction in number of leaves. At the end of the development stage, number of opened leaves significantly $(P \leq 0.05)$ increased from 19 to 22 leaves under 11 days drought and to 21 leaves under 13 and 15 days droughts but 5-9 days drought periods had no significant $(P>0.05)$ effect on number of opened leaves at the development stage. At the mid-stage, drought length had no significant $(P>0.05)$ effect on number of opened leaves (Table 4).

\section{Leaf area index (LAI)}

Results indicate that as drought length increased LAI decreased at all growth stages (Table 5). Analysis of variance indicated that LAI at the initial stage was significantly $(P \leq 0.05)$ highest for the control $(0.013)$ and lowest (0.005) for 15 days drought stressed plants. Plants subjected to 5,11, 13 and 15 days droughts at the initial stage were significantly reduced of their LAI by $30.8 \%$, $53.8 \%, 46.2 \%$ and $61.5 \%$ respectively whilst 7 and 9 days droughts significantly reduced LAI at the initial stage by $30.5 \%$ compared to the control. LAI at the development stage was significantly $(P \leq 0.05)$ reduced only under 15 days drought. The control plants recorded the highest LAI of 0.043 followed by 5 days drought (0.039) with 15 days drought stressed plants recording the significantly $(P \leq 0.05)$ lowest $(0.033)$ which was $23.3 \%$ lower than that of the control plants. At the mid-stage, significant reductions of $18.6 \%, 25.6 \%, 30.2 \%$ and $37.2 \%$ occurred in
LAI under 9, 11, 13 and 15 days of droughts respectively as compared to the control.

\section{Leaf chlorophyll content index (CCI)}

Leaf chlorophyll content index generally decreased as drought length advanced regardless of growth stage (Table 6). Leaf chlorophyll content was significantly $(P$ $\leq 0.05)$ decreased under 13 and 15 days drought occurring at the initial stage $(12.96 \%$ and $15.91 \%$ respectively) compared to the control. At the development stage, leaf chlorophyll content index was significantly $(P \leq 0.05)$ reduced under each of the applied drought periods compared to the control. Significant reductions of $11.8 \%$, $15.1 \%, 17 \%, 17.9 \%, 49.7 \%$ and $48.9 \%$ were due to $5,7,9$, 11,13 and 15 days drought respectively. Similar to the development stage, chlorophyll content index of cabbage leaf at the mid-stage was significantly $(P \leq 0.05)$ reduced by all applied drought periods compared to the control. Significant reductions of $10.8 \%, 12.9 \%, 12.7 \%$ and $48.9 \%$ were due to $5,7,9$ and 15 days droughts respectively whilst 11 and 13 days droughts reduced leaf chlorophyll content by $17.2 \%$ at the mid-stage.

\section{Head size/girdle at harvest $(\mathrm{cm})$}

Head size, when compared across the growth stages generally increased from the initial stage to the mid-stage (initial $<$ development $<$ mid), indicating a decreasing effect of the same drought period on head size as the crop advances from one stage to another, with head size at the initial stage being significantly $(P \leq 0.05)$ lowest $(57.56 \mathrm{~cm})$ compared to the development and mid stages (61.47 $\mathrm{cm}$ and $61.96 \mathrm{~cm}$ respectively) (Table 7).
Table 5 Mean LAI as influenced by drought length at different growth stages of $B$. oleracea var capitata

\begin{tabular}{llllllllll}
\hline Growth stage & \multicolumn{1}{l}{ Drought length (days) } & & & LSD & CV (\%) \\
\cline { 2 - 7 } & 0 & 5 & 7 & 9 & 11 & 13 & 15 & & \\
\hline Initial & $0.013^{\mathrm{a}}$ & $0.009^{\mathrm{b}}$ & $0.008^{\mathrm{bc}}$ & $0.008^{\mathrm{bc}}$ & $0.006^{\mathrm{c}}$ & $0.007^{\mathrm{b}}$ & $0.005^{\mathrm{c}}$ & 0.002 & 15.5 \\
Development & $0.043^{\mathrm{a}}$ & $0.039^{\mathrm{a}}$ & $0.039^{\mathrm{a}}$ & $0.039^{\mathrm{a}}$ & $0.035^{\mathrm{b}}$ & $0.034^{\mathrm{ab}}$ & $0.033^{\mathrm{ab}}$ & 0.009 & 13.8 \\
Mid & $0.043^{\mathrm{a}}$ & $0.039^{\mathrm{ab}}$ & $0.038^{\mathrm{ab}}$ & $0.035^{\mathrm{bc}}$ & $0.032^{\text {cd }}$ & $0.030^{\mathrm{cd}}$ & $0.027^{\mathrm{d}}$ & 0.005 & 8.7 \\
\hline
\end{tabular}

Between column means bearing different superscripts differ significantly $(P \leq 0.05)$ 
Table 6 Mean leaf chlorophyll content index (CCI) as influenced by drought length at different growth stages of $B$. oleracea var capitata

\begin{tabular}{|c|c|c|c|c|c|c|c|c|c|}
\hline \multirow[t]{2}{*}{ Growth stage } & \multicolumn{7}{|c|}{ Drought length (days) } & \multirow[t]{2}{*}{ LSD } & \multirow[t]{2}{*}{$\mathrm{CV}(\%)$} \\
\hline & 0 & 5 & 7 & 9 & 11 & 13 & 15 & & \\
\hline Initial & $80.35^{\mathrm{a}}$ & $78.16^{\mathrm{a}}$ & $79.27^{\mathrm{a}}$ & $78.98^{\mathrm{a}}$ & $72.27^{\mathrm{ab}}$ & $69.90^{\mathrm{b}}$ & $67.57^{\mathrm{b}}$ & 5.986 & 4.5 \\
\hline Development & $80.35^{\mathrm{a}}$ & $70.86^{\mathrm{b}}$ & $68.21^{\mathrm{b}}$ & $66.66^{\mathrm{b}}$ & $66.00^{\mathrm{b}}$ & $40.45^{\mathrm{c}}$ & $41.07^{\mathrm{c}}$ & 2.407 & 4.8 \\
\hline Mid & $80.35^{\mathrm{a}}$ & $72.83^{\mathrm{b}}$ & $71.64^{\mathrm{b}}$ & $70.00^{\mathrm{bc}}$ & $70.18^{b c}$ & $66.49^{c}$ & $66.51^{\mathrm{c}}$ & 4.712 & 3.7 \\
\hline
\end{tabular}

Between column means bearing different superscripts differ significantly $(P \leq 0.05)$
Generally, head size due to drought length within a particular growth stage significantly $(P \leq 0.05)$ decreased with increasing drought length from $66.46 \mathrm{~cm}$ without drought to $54.88 \mathrm{~cm}$ under 15 days drought. Significant reductions of $3.64 \%, 9.04 \%, 10.53 \%, 10.79 \%, 13.17 \%$ and $17.42 \%$ were due to $5,7,9,11,13$ and 15 days of drought compared to the control.

Interacting growth stage with drought length indicated that all applied drought periods at the initial stage significantly $(P \leq 0.05)$ decreased final head size as compared to the control. All but 5 days drought occurring at the development and mid stages significantly $(P \leq 0.05)$ decreased final head size as compared to the control. Overall, the minimum head size $(52.88 \mathrm{~cm})$ was recorded under 15 days drought occurring at the initial stage which was $20.4 \%$ lower than that of the control. Seven (7) days drought occurring at the initial, development and mid stages significantly decreased final head size by $11.7 \%$, $7.9 \%$ and $7.5 \%$ respectively. Nine (9) days drought at the initial, development and mid stages decreased head size by $17.1 \%, 7.6 \%$ and $6.8 \%$ whilst 11 days drought had $18.2 \%$, $7.3 \%$ and $6.9 \%$ significant reductions respectively compared to the control. 13 days drought resulted in $19.5 \%$, $10.3 \%$ and $9.7 \%$ whilst 15 days drought at the respective growth stages decreased final head size by $20.4 \%, 16.7 \%$ and $15.1 \%$ compared to the control.

\section{Yield (tons/ha)}

Similar to head size, yield of cabbage generally increased across the growth stages from initial to mid for each drought period (initial $<$ development $<$ mid) (Table 7). Yield of cabbage differed significantly amongst the three growth stages with the yield due to drought at the initial stage (36.25 tons/ha) being the significantly $(P \leq 0.05)$ lowest compared to those at the development (39.10 tons/ ha) and mid stages (44.56 tons/ha).

Yield also decreased with increasing drought within a particular stage. Five (5) days drought had no significant $(P>0.05)$ effect on yield whilst the rest of the applied drought periods significantly $(P \leq 0.05)$ reduced yield compared to the control. Five (5) and 7 days drought periods differed significantly $(P \leq 0.05)$ from the rest.
Nine (9) and 15 days drought differed significantly ( $P$ $\leq 0.05)$ in terms of yield but both statistically similar $(P>0.05)$ to 11 and 13 days droughts.

Interactively (drought length * growth stage), five (5) days drought at any of the growth stages and 7 days drought at the development and mid stages had no significant $(P>0.05)$ effect on final yield compared to the control. Drought beyond 5 days at the initial stage and drought beyond 7 days at the development and mid stages significantly $(P \leq 0.05)$ decreased yield compared to the control. The control plants produced a maximum yield of 52.59 tons/ha which was $53.4 \%$ higher than the minimum yield of 24.5 tons/ha produced by plants subjected to 15 days drought during the initial stage. Subjecting the initial stage to $7,9,11$ and 13 days drought resulted in significant yield reductions of $22 \%, 44.2 \%, 45.2 \%$ and $48.3 \%$ respectively compared to the control. Nine (9), 11 , 13 and 15 days droughts at the development stage caused $34.0 \%, 36.9 \%, 43.9 \%$ and $47.8 \%$ significant yield reductions respectively whereas $9,11,13$ and 15 days droughts at the mid stage decreased yield by $21.0 \%, 25.0 \%, 22.7 \%$ and $24.6 \%$ respectively compared to the control.

\section{Measured parameters and their critical length of drought (days)}

Critical drought length from which the measured parameters started experiencing significant reduction are presented in Table 8. Drought duration of 5 days and beyond at the initial stage were critical for number of opened leaves, LAI and head size whereas 13 and 7 days length of drought at the initial stage were critical against chlorophyll content index and yield respectively. At the development stage, 11 days drought was critical against number of opened leaves and LAI, 5 days was critical against chlorophyll content index whilst 7 days was critical against both yield components. At the mid stage, number of opened leaves was not affected by drought length. However, 9 days drought at the mid stage was critical against LAI and yield whereas 5 and 7 days drought were critical for chlorophyll content index and head size respectively. 
Table 7 Effect of Drought Length at different growth stages of $B$. oleracea var capitata on final head size/girth $(\mathrm{cm})$ and yield (tons/ha)

\begin{tabular}{|c|c|c|}
\hline Treatment & Head size/girth $(\mathrm{cm})$ & Yield (tons/ha) \\
\hline \multicolumn{3}{|l|}{ Growth stage } \\
\hline Initial (I) & $57.56^{\mathrm{a}}$ & $36.25^{\mathrm{a}}$ \\
\hline Development (D) & $61.47^{\mathrm{b}}$ & $39.10^{\mathrm{b}}$ \\
\hline Mid (M) & $61.96^{\mathrm{b}}$ & $44.56^{\mathrm{c}}$ \\
\hline LSD (0.05) & 1.553 & 2.398 \\
\hline \multicolumn{3}{|c|}{ Drought length (days) } \\
\hline 0 & $66.46^{\mathrm{a}}$ & $52.59^{\mathrm{a}}$ \\
\hline 5 & $64.04^{\mathrm{b}}$ & $50.99^{\mathrm{a}}$ \\
\hline 7 & $60.45^{\mathrm{c}}$ & $44.19^{\mathrm{b}}$ \\
\hline 9 & $59.46^{\mathrm{c}}$ & $35.20^{\mathrm{c}}$ \\
\hline 11 & $59.29^{c}$ & $33.83^{\mathrm{cd}}$ \\
\hline 13 & $57.71^{\mathrm{c}}$ & $32.44^{\mathrm{cd}}$ \\
\hline 15 & $54.88^{\mathrm{d}}$ & $30.54^{\mathrm{d}}$ \\
\hline LSD (0.05) & 2.372 & 3.664 \\
\hline \multicolumn{3}{|l|}{ Interactions } \\
\hline $0 * \mathrm{I}$ & $66.46^{\mathrm{a}}$ & $52.59^{\mathrm{a}}$ \\
\hline $0 * \mathrm{D}$ & $66.46^{\mathrm{a}}$ & $52.59^{\mathrm{a}}$ \\
\hline $0 * \mathrm{M}$ & $66.46^{\mathrm{a}}$ & $52.59^{\mathrm{a}}$ \\
\hline $5 * \mathrm{I}$ & $61.94^{\mathrm{bc}}$ & $50.26^{\mathrm{ab}}$ \\
\hline $5 * \mathrm{D}$ & $64.67^{\mathrm{abd}}$ & $50.98^{\mathrm{ab}}$ \\
\hline $5 * \mathrm{M}$ & $65.50^{\mathrm{ab}}$ & $51.72^{\mathrm{a}}$ \\
\hline $7 * I$ & $58.67^{\mathrm{ce}}$ & $41.04^{\text {bd }}$ \\
\hline $7 * \mathrm{D}$ & $61.20^{\mathrm{cd}}$ & $45.24^{\text {bd }}$ \\
\hline $7 * \mathrm{M}$ & $61.49^{\mathrm{bc}}$ & $46.30^{\mathrm{ab}}$ \\
\hline $9 * \mathrm{I}$ & $55.10^{\mathrm{ef}}$ & $29.37^{\mathrm{cf}}$ \\
\hline $9 * \mathrm{D}$ & $61.38^{\mathrm{cd}}$ & $34.69^{\mathrm{ce}}$ \\
\hline $9 * \mathrm{M}$ & $61.91^{\mathrm{bc}}$ & $41.56^{\text {bd }}$ \\
\hline $11 * \mathrm{I}$ & $54.36^{\mathrm{f}}$ & $28.83^{\mathrm{cf}}$ \\
\hline $11 * \mathrm{D}$ & $61.64^{\mathrm{bc}}$ & $33.20^{\mathrm{cef}}$ \\
\hline $11 * \mathrm{M}$ & $61.88^{\mathrm{bc}}$ & $39.46^{\mathrm{de}}$ \\
\hline $13 * I$ & $53.50^{f}$ & $27.19^{f}$ \\
\hline $13 * \mathrm{D}$ & $59.59^{\mathrm{ce}}$ & $29.50^{\mathrm{cf}}$ \\
\hline $13 * \mathrm{M}$ & $60.03^{c}$ & $40.63^{\text {bd }}$ \\
\hline $15 * \mathrm{I}$ & $52.88^{\mathrm{f}}$ & $24.50^{\mathrm{f}}$ \\
\hline $15 * \mathrm{D}$ & $55.33^{\text {ef }}$ & $27.46^{\mathrm{f}}$ \\
\hline $15^{*} \mathrm{M}$ & $56.43^{\text {ef }}$ & $39.67^{\mathrm{de}}$ \\
\hline LSD (0.05) & 4.109 & 6.346 \\
\hline CV \% & 4.1 & 9.6 \\
\hline
\end{tabular}

Between column means bearing different superscripts differ significantly $(P \leq 0.05)$

\section{Discussion}

\section{Number of opened leaves/plant}

Lesser leave numbers at the initial stage might be due to decreased leaf formation and growth. Increased number of opened leaves at the development stage is attributable to delayed cupping due to drought stress. At the mid-stage however, heads had already formed and drought stress would have no effect on the number of outer leaves. Decreasing number of leaves at the initial stage was critical even under 5 days drought whereas an increase in the number of opened leaves due to delayed cupping at the development stage was critical under 11 days drought (Table 8). Lalinia et al. (2012) reported that drought stress at the flowering stage decreased number of branches in mungbean. Gupta et al. (1995) also reported reduced number of branches in chickpea when drought was imposed at the early flowering stage. In the present study, the initial stage of B. oleracea var capitata appeared to be most sensitive to increasing drought length than the development and mid stages in terms of leave number. According to Kabiri et al. (2014), drought stress at the vegetative stage is of less importance than at the reproductive stage of tension with regards to impact on yield and yield components. However, drought stress at the vegetative stage impacts leaf and stem development, photosynthesis, and the accumulation of important plants components (Fathi and Tari 2016). The biophysical factors mostly affected are the size and number of leaves in plants (Ghodsi et al. 1998).

\section{Leaf area index (LAI)}

Restriction on leaf area is the first line of defense against water stress. Similar to number of leaves, the initial stage was most sensitive to increasing drought in terms of LAI as reduction in LAI at this stage was observed under 5 days drought and beyond. Whereas at the development and mid stages critical drought periods were 11 and 9 days respectively (Table 8 ). Reduced LAI at the various growth stages were due to already mentioned factors that resulted in the decrease in the number and size of opened leaves. LAI results from this study are in agreement with that of Rao and Bhatt (1988) who reported reduction in leaf area of Capsicum annum L. to drought stress at all the growth stages, viz., vegetative, flowering and fruiting.

\section{Leaf Chlorophyll content index (CCI)}

Decrease in leaf chlorophyll content index due to drought stress is considered a typical symptom of pigment photo 
Table 8 Measured parameters and their critical length of drought (days) at different growth stages

\begin{tabular}{|c|c|c|c|c|c|}
\hline \multirow[t]{2}{*}{ Growth stage } & \multicolumn{2}{|l|}{ Parameter } & \multirow[b]{2}{*}{ Chlorophyll content index $(\mathrm{CCI})$} & \multirow[b]{2}{*}{ Head size $(\mathrm{Cm})$} & \multirow[b]{2}{*}{ Yield (tons/ha) } \\
\hline & Number of opened leaves & LAI & & & \\
\hline Initial & 5 & 5 & 13 & 5 & 7 \\
\hline Development & 11 & 11 & 5 & 7 & 7 \\
\hline Mid & ns & 9 & 5 & 7 & 9 \\
\hline
\end{tabular}

$n s$ non-significant

oxidation and chlorophyll degradation (Anjum et al. 2011). A decrease in total chlorophyll content index with increasing drought stress implies a lowered capacity for light harvesting. Since the production of reactive oxygen species mainly depends on excess energy absorption in the photosynthetic apparatus, this might be avoided by degrading the absorbing pigments (Mafakheri et al. 2010). In relation to chloroplastic protein hydrolysis and decreasing leaf pigments (Sgherri et al. 1993), it could be expressed that drought effect on chlorophyll in leaf due to drought is a primary stage in degradation of proteins. Also, the decrease in chlorophyll under drought stress might be as a result of reduced synthesis of the main chlorophyll pigment complexes encoded by the $c a b$ gene family (Allakhverdiev et al. 2000). Decreased chlorophyll content may also be attributed to reduced dry matter production as a result of reduced leaf photosynthesis. This effect is in agreement with the findings of Premachandra et al. (1991) who reported 67-97\% lower leaf photosynthesis in stressed maize plants than in watered plants. Critical drought periods for chlorophyll reduction were observed under 13 days drought at the initial stage whereas even 5 days drought at the development and mid stages led to chlorophyll reduction, indicating that the development and mid stages were most sensitive to increasing drought in terms of chlorophyll content.

\section{Head size/girdle at harvest $(\mathrm{cm})$}

Final head size was influenced by the number of leaves, leaf area and the amount of energy intercepted throughout the growth period. Lower values of head size due to drought effect at the initial stage may be as a result of decreased leaf formation potential indicated as reduced leave numbers and sizes. Although decrease in amount of chlorophyll at the initial stage under short and moderate droughts were not significant, consequences on growth significantly affected leaf numbers and sizes which subsequently reduced head size at maturity. Decreased head sizes due to drought period beyond 5 days at the development stage may be as a result of the delayed cupping which led to increased number of opened leaves (Table 4, development stage), especially under 11-15 days drought. During this stage, leaves are expected to form heads but became flaccid under lengthy water stress and as a result remained opened around the head. Also, leaf senescence after rapid vegetative growth led to reduced amount of leaf chlorophyll which consequently reduced tissue formation thereby reducing leave sizes at the mid stage. According to $\mathrm{Xu}$ and Leskovar (2014), even 50\% and 75\% deficit irrigation applied before and after head formation of cabbage significantly decreased final head size. They also reported significant reduction in head size under $50 \%$ deficit irrigation applied to the head formation stage. Interacting growth stage with drought length indicated reduced head size even under 5 days drought at the initial stage whereas at the development and mid stages this was critical at 5 days drought.

\section{Yield (tons/ha)}

Generally, yield reduction was greater when the initial stage was subjected to drought irrespective of the length. Also yield reduction was observed even under 7 days drought at the initial and development stages whereas at the mid stage yield reduction was critical under 9 days drought. Water stress during the initial stage reduces yield by reducing leave number and sizes or area while drought stress at the development stage reduces yield by decreasing the number of leaves that entered into the head. Drought stress at the mid stage however reduces yield by reducing the plant of its moisture content which subsequently decreased head weight. Decrease in chlorophyll content at any stage also affects the formation of new tissues which consequently decrease the final head weight. According to MoFA average yields of 30-40 tons/ha are normal. FAO (2018) also stated that a maximum of about 50 tons/ha can be obtained when sprayed and well-fertilized. Under ideal climatic conditions and good irrigation and crop management, yields can be as high as 85 tons/ha (FAO 2018). Moradi et al. (2008) reported that drought stress at the 
vegetative and reproductive stages reduced mungbean seed yield by 9 and $49 \%$ respectively.

\section{Conclusions}

Significant changes in number of opened leaves at the initial and development stages were critical under 5 and 11 days drought respectively. Reduction in LAI at the initial, development and mid stages were critical under 5, 11 and 9 days respectively. Chlorophyll content index was reduced under critical drought periods of 13 days at the initial stage and 5 days at both the development and mid stages. Number of opened leaves was however not affected by drought occurrence at the mid stage.

Projected reduction effect of drought on head size at harvest was critical under 5 days drought at the initial stage and 7 days drought at the development and mid stages. Since yield reduction was critical under 7 days drought at the initial and development stages as well as under 9 days drought at the mid stage, it suggest that implementing water application at regular intervals of 7 days at the initial and development stages as well as 9 days at the mid stage could maintain economic yield although growth may be moderately suppressed.

Acknowledgement The Authors thank the Meteorological Service Department, Mampong-Ashanti Agency for providing climate data (ETos) for scheduling our irrigation system.

Author contributions RK conceived the original idea. Both Authors contributed to the experimental designed. EA carried out the experiment, performed analytical computations and wrote the first draft of the manuscript. RK supervised the project and commented on previous versions of the manuscript. Both Authors read and approved the final manuscript for submission.

\section{Compliance with ethical standards}

Conflict of interest The Authors declare that they have no conflict of interest.

Ethical approval The studies involved in this article did not included animals or human participants as objects of research.

Open Access This article is licensed under a Creative Commons Attribution 4.0 International License, which permits use, sharing, adaptation, distribution and reproduction in any medium or format, as long as you give appropriate credit to the original author(s) and the source, provide a link to the Creative Commons licence, and indicate if changes were made. The images or other third party material in this article are included in the article's Creative Commons licence, unless indicated otherwise in a credit line to the material. If material is not included in the article's Creative Commons licence and your intended use is not permitted by statutory regulation or exceeds the permitted use, you will need to obtain permission directly from the copyright holder. To view a copy of this licence, visit http://creativecommons. org/licenses/by/4.0/.

\section{References}

Al-Ghobari, H. M. (2012). A comparison of water application uniformity for drip irrigation system above and below soil surface at various soil depths and scheduling techniques in arid region. WIT Transactions on Ecology and the Environment, 168, 311-322.

Allakhverdiev, S. I., Sakamoto, A., Nishiyama, Y., \& Murata, N. (2000). Inactivation of photosystems I and II in response to osmotic stress in Synechococcus. Contribution of water channels. Plant Physiology, 122(4), 1201-1208.

Anjum, S. A., Xie, X. Y., Wang, L. C., Saleem, M. F., Man, C., \& Lei, W. (2011). Morphological, physiological and biochemical responses of plants to drought stress. African Journal of Agricultural Research, 6(9), 2026-2032.

Arku, A. Y., Musa, S. M., \& Mofoke, A. L. E. (2012). Determination of water requirement and irrigation timing for Amaranthus hybridus in Maiduguri metropolis, north-eastern Nigeria. In Fourth international conference on sustainable irrigation (pp. 279-289).

Asif, M., Ahmad, M., Mangrio, A. G., Akbar, G., \& Memon, A. H. (2015). Design, evaluation and irrigation scheduling of drip irrigation system on citrus orchard. Pakistan Journal of Meteorology, 12(23), 37-48.

Baiphethi, M. N., \& Jacobs, P. T. (2009). The contribution of subsistence farming to food security in South Africa. Agrekon, 48(4), 459-482.

Blankson, A. W., Gurr, G. M., Gitau, C. W., Nicol, H. I., Munyakazi, L., \& Stevenson, P. C. (2013). Tri-trophic insecticidal effects of African plants against cabbage pests. PLOS ONE, 8(10), e78651. https://doi.org/10.1371/journal.pone.0078651.

Challinor, A. J., Watson, J., Lobell, D. B., Howden, S. M., Smith, D. R., \& Chhetri, N. (2014). A meta-analysis of crop yield under climate change and adaptation. Nature Climate Change, 4(4), 287.

Dudek, T. A., \& Fernandez, R. T. (2015). Conducting a water application uniformity evaluation for an overhead sprinkler irrigation system in the nursery (p. 15). Consultado: Michigan State University Extension.

Ezeaku, I. E., Okechukwu, E. C., \& Aba, C. (2014). Climate change effects on maize (Zea mays) production in Nigeria and strategies for mitigation. Asian Journal of Science and Technology, 5, $862-871$.

Food and Agriculture Organization (FAO). (2018). Crop description and climate|Cabbage. Available at: https://www.fao.org/landwater/databases-andsoftware/cropinformation/cabbage/en/.

Fathi, A., \& Tari, D. (2016). Effect of drought stress and its mechanism in plants. International Journal of Life Sciences, 10(1), 1-6. https://doi.org/10.3126/ijls.v10i1.14509.

Ghodsi, M., Nazeri, M., \& Zarea-Fizabady, A. (1998). The reaction of new cultivars and elite lines of spring wheat into drought stress. In Collection of abstract articles of 5th Iranian agronomy and plant breeding conference, Karaj, Iran (p. 252).

Grzywacz, D., Rossbach, A., Rauf, A., Russell, D. A., Srinivasan, R., \& Shelton, A. M. (2010). Current control methods for diamondback moth and other brassica insect pests and the prospects for improved management with lepidopteran-resistant Bt vegetable brassicas in Asia and Africa. Crop Protection, 29(1), 68-79.

Gupta, S. N., Dahiya, B. S., Malik, B. P. S., \& Bishnoi, N. R. (1995). Response of chickpea to water deficits and drought stress. Haryana Agriculture University Journal of Research, 25(1/2), 11-19. 
Hedhly, A., Hormaza, J. I., \& Herrero, M. (2009). Global warming and sexual plant reproduction. Trends in Plant Science, 14(1), $30-36$.

IPCC, 2007 Climate Change. (2007). Impacts, adaptation and vulnerability. In M. L. Parry, O. F. Canziani, J. P. Palutikof, P. J. van der Linden, \& C. E. Hanson (Eds.), Contribution of working group II to the fourth assessment report of the intergovernmental panel on climate change (p. 976). Cambridge, UK: Cambridge University Press.

Kabiri, R., Nasibi, F., \& Farahbakhsh, H. (2014). Effect of exogenous salicylic acid on some physiological parameters and alleviation of drought stress in Nigella sativa plant under hydroponic culture. Plant Protection Science, 50(1), 43-51.

Kidane, D. (2016). Assessment of cabbage production practices and effect of NP fertilizer rate on head yield and yield components in Lay Armacheho district. Doctoral dissertation, Bahir Dar University.

Kotei, R., Agyare, W. A., Kyei-Baffour, N., Frempong, N. K., \& AttaDarkwa, T. (2015). Development of groundwater recharge model for the sumanpa catchment at Ashanti-Mampong-Ashanti Area in Ghana.

Lalinia, A. A., Hoseini, N. M., Galostian, M., Bahabadi, S. E., \& Khameneh, M. M. (2012). Echophysiological impact of water stress on growth and development of mungbean. International Journal of Agronomy and Plant Production, 3(12), 599-607.

Mafakheri, A., Siosemardeh, A. F., Bahramnejad, B., Struik, P. C., \& Sohrabi, Y. (2010). Effect of drought stress on yield, proline and chlorophyll contents in three chickpea cultivars. Australian Journal of Crop Science, 4(8), 580-585.

Maggio, A., De Pascale, S., Ruggiero, C., \& Barbieri, G. (2005). Physiological response of field-grown cabbage to salinity and drought stress. European Journal of Agronomy., 23, 57-67. https://doi.org/10.1016/j.eja.2004.09.004.

Majumdar, S., Ghosh, S., Glick, B. R., \& Dumbroff, E. B. (1991). Activities of chlorophyllase, phosphoenolpyruvate carboxylase and ribulose-1, 5-bisphosphate carboxylase in the primary leaves of soybean during senescence and drought. Physiologia Plantarum, 81(4), 473-480.
Moradi, A., Ahmadi, A., \& Hossein Zadeh, A. (2008). Agrophysiological responses of mung bean (cv. Partov) to severe and moderate drought stress applied at vegetative and reproductive growth stages. JWSS-Isfahan University of Technology, 12(45), 659-671.

Paclik, R. L., \& Sakova, C. V. (1996). Reaction of different cultivars of Brassica napussubsp. oleifera to water stress. FytotechnickaRada, 1, 55-62.

Premachandra, G. S., Saneoka, H., Kanaya, M., \& Ogata, S. (1991). Cell membrane stability and leaf surface wax content as affected by increasing water deficits in maize. Journal of experimental botany, 42(2), 167-171.

Rao, S., \& Bhatt, R. M. (1988). Photosynthesis, transpiration, stomatal diffuse resistance, and relative water content of capsicum (Bell Pepper) grown under water stress. Photosynthetica (Praha), 22(3), 377-382.

Scurlock, J. M. O., Asner, G. P., \& Gower, S. T. (2001). Worldwide historical estimates of leaf area index, 1932-2000. ORNL/TM2001/268, p. 34.

Sgherri, C. L. M., Pinzino, C., \& Navari-Izzo, F. (1993). Chemical changes and $\mathrm{O}_{2}$-production in thylakoid membranes under water stress. Physiologia Plantarum, 87(2), 211-216.

Shannon, M. C., \& Grieve, C. M. (1998). Tolerance of vegetable crops to salinity. Scientia horticulturae, 78(1-4), 5-38.

Timbilla, J. A., \& Nyarko, K. O. (2004). A survey of cabbage production and constraints in Ghana. Ghana Journal of Agricultural Science, 37(1), 93-101.

Williamson, S., Ball, A., \& Pretty, J. (2008). Trends in pesticide use and drivers for safer pest management in four African countries. Crop Protection, 27(10), 1327-1334.

Xu, C., \& Leskovar, D. I. (2014). Growth, physiology and yield responses of cabbage to deficit irrigation. Horticultural Science (Prague), 41, 138-146.

Publisher's Note Springer Nature remains neutral with regard to jurisdictional claims in published maps and institutional affiliations. 